\title{
CLINICAL ASPECTS OF EXPERIMENTAL PERITONITIS IN HORSES ${ }^{1}$
}

\author{
ASPECTOS CLÍNICOS DA PERITONITE EXPERIMENTAL EM EQÜINOS
}

\author{
Luiz Cláudio Nogueira Mendes ${ }^{2}$ Luiz Carlos Marques ${ }^{3}$ \\ Ruben Pablo Schocken-Iturrino ${ }^{4}$ Fernando Antônio de Ávila $^{4}$
}

\section{SUMMARY}

Sixteen adult horses were randomly divided into 4 equal groups (GI, GII, GIII and GIV) of 4 animals and each group was injected intraperitoneally with one of the following suspension: GI (100 $\times 10^{7}$ colony-forming units (CFU) of Escherichia coli diluted in $500 \mathrm{ml}$ of $0.9 \%$ saline $) ; \mathrm{GII}\left(100 \times 10^{7}\right.$ CFU of Bacteroides fragilis in $500 \mathrm{ml}$ of $0.9 \%$ saline); GIII $(100 x$ $10^{7} \mathrm{CFU}$ of $\boldsymbol{E}$. coli in combination with $100 \times 10^{7} \mathrm{CFU}$ of $\boldsymbol{B}$. fragilis in $500 \mathrm{ml}$ of $0.9 \%$ saline); GIV (500ml of $0.9 \%$ saline). Abdominal wall sensitivity to external pressure and tension, diarrhea, decreased intestinal sounds and increased of heart rate were the clinical signs more frequently observed in inoculated horses. Horses inoculated with pure cultures of either $\boldsymbol{E}$. coli or B. fragilis demonstrated mild and self-limiting peritonitis, while those inoculated with the combination of both bacteria demonstrated clinical signs of higher intensity and duration.

Key words: peritonitis, horses, Escherichia coli, Bacteroides fragilis.

\section{RESUMO}

Dezesseis eqüinos adultos foram distribuídos aleatoriamente em 4 grupos (GI, GII, GIII e GIV), constituídos por quatro animais, recebendo cada grupo o seguinte inóculo por via intraperitoneal: GI (100 X $10^{7}$ unidades formadoras de colônia (UFC) de Escherichia coli diluídos em $500 \mathrm{ml}$ de salina 0,9\%); GII (100 X $10^{7}$ UFC de Bacteroides fragilis diluídos em $500 \mathrm{ml}$ de salina 0,9\%); GIII (100 X 107 UFC de E. coli associados a $100 \times 10^{7}$ UFC de B. fragilis diluídos em $500 \mathrm{ml}$ de salina 0,9\%); GIV (testemunho - 500ml de salina 0,9\%). Aumento da sensibilidade e tensão da parede abdominal, diarréia, diminuição dos sons intestinais e aumento da freqüência cardíaca foram os sinais mais freqüentemente observados nos eqüinos inoculados com cepas bacterianas. Eqüinos inoculados com culturas puras de $\boldsymbol{E}$. coli ou $\boldsymbol{B}$. fragilis apresentaram peritonites brandas e autolimitantes, enquanto que os inoculados com a associação dessas bactérias apresentaram sinais de maior intensidade e duração.

\author{
Palavras-chave: peritonite, eqüinos, Escherichia coli, \\ Bacteroides fragilis.
}

\section{INTRODUCTION}

Peritonitis may be induced by any contaminant or irritating agent. It is a complex disease characterized by multiple organ involvement (HOSGOOD \& SALISBURY, 1989). Horses have always been considered to be highly susceptible to peritonitis (SCHNEIDER, 1992) and their susceptibility has been tentatively attributed to the equine omentum being smaller than that of other species (MAIR et al., 1990). It was considered a potentially fatal or permanently incapacitating condition, and has been identified as a major postoperative complication of surgical colic (RICKETTS, 1987). There have been few detailed studies on peritonitis in adult horses (MAIR $\boldsymbol{e t}$ al., 1990). Much of the knowledge about peritonitis has been determined through studies on laboratory species and humans (TRENT, 1995).

The clinical signs of horses with naturally acquired peritonitis are abdominal pain, ileus, hyperthermia or normothermia, abdominal distention, anorexia, weight loss and diarrhea or constipation (COFFMAN \& TRISCHLER, 1972; DYSON, 1983; CLABOUGH \& DUCKETT, 1992; MOLL \& SCHUMACHER, 1992). Horses with acute diffuse peritonitis also show prolonged capillary refill time, dehydration, increased heart and respiratory rates, pawing, depression, anorexia, red-

\footnotetext{
${ }^{1}$ Supported by FAPESP

${ }^{2}$ Médico Veterinário, MSc., Professor Assistente, Departamento de Clínica, Cirurgia e Reprodução Animal - UNESP, Araçatuba, Brazil.

${ }^{3}$ Médico Veterinário, Doutor, Professor Adjunto do Departamento de Clínica e Cirurgia Veterinária - FCAV, UNESP, 14870-000, Jabo-

ticabal, Brazil. E-mail: lmarques@fcav.unesp.br. Author for correspondence.

${ }^{4}$ Médico Veterinário, Doutor, Professor Titular do Departamento de Microbiologia da FCAV - UNESP.

Recebido para publicação em 11.08.98. Aprovado em 04.11.98
} 
to-purple mucous membranes and muscle fasciculation (MAIR et al., 1990). Abdominal pain is most evident in the early stages of disease and is characterized by reluctance to move, splinting of the abdominal wall, and sensitivity to external abdominal pressure (SEMRAD, 1990).

$\boldsymbol{E}$. coli and $\boldsymbol{B}$. fragilis are present in the normal flora of gastrointestinal tract and most cases of peritonitis in horse are caused by these agents (COFFMAN \& TRISCHLER, 1972; MAIR $\boldsymbol{e t}$ al. 1990; MOLL \& SCHUMACHER, 1992). Fifty-six per cent of the positive samples yielded one of these species and 26 per cent yielded the both species (SEMRAD, 1990). The association between obligate anaerobes and facultative organisms enhances the virulence of some bacteria that are relatively nonpathogenic in normal circumstances. Mixed infection by these two bacteria in horse peritonitis has synergic effects (MOORE, 1993).

The principal goal of the present experiment was to study the clinical alterations of equine experimental peritonitis caused by $\boldsymbol{E}$. coli or B. fragilis or by the combination of these two agents.

\section{MATERIAL AND METHODS}

Sixteen healthy horses (twelve male and four female not pregnant) of various breeds, ranging from 3 to 10 years were used. The horses were randomized in four groups (GI, GII, GIII and GIV) of four animals each. During the study the horses were housed in individual stalls, fed ration with $12 \%$ protein (3 kg/animal/day), coast-cross (Cynodon dactilon $\mathbf{L}$.) hay and water ad libitum.

B. fragilis was isolated from a human patient with peritonitis in the University Hospital, Faculty of Medicine of Ribeirão Preto - São Paulo University, and was cultivated at the Anaerobic Laboratory of the Faculty of Agronomic and Veterinary Sciences, Campus of Jaboticabal, São Paulo State University, using JANG \& HIRSH (1991) method. $\boldsymbol{E}$. coli was isolated from a sample of feces from a healthy horse at the same university, using EDWARDS \& EWING (1972) method. The inoculum was standardized as $10 \times 10^{7}$ colonyforming units (CFU) per milliliter.

For the inoculations, paracentesis was performed according to the technique described by WHITE II (1990), and the horses were inoculated intraperitoneally as described in table 1 . All animals were examined at $0,2,4,6,8,10,12,24,36,48,60$, $72,120,168$ and 216 hours after inoculation (HAI). Clinical records included rectal temperature, heart and respiratory rates, color of the mucus membranes,
Table 1 - Treatment of horses by intraperitoneal injection.

Group Inoculum/dose

$\begin{array}{ll}\text { I } & \text { E. coli }\left(100 \times 10^{7} \mathrm{CFU}\right)+500 \mathrm{ml} \text { of } 0.9 \% \text { saline } \\ \text { II } & \text { B. fragilis }\left(100 \times 10^{7} \mathrm{CFU}\right)+500 \mathrm{ml} \text { of } 0.9 \% \\ & \text { saline } \\ \text { III } & \begin{array}{l}\text { E. } \boldsymbol{c o l i}\left(100 \times 10^{7} \mathrm{CFU}\right)+\boldsymbol{B} \text {. fragilis }\left(100 \times 10^{7}\right. \\ \text { CFU }+500 \mathrm{ml} \text { of } 0.9 \% \text { saline }\end{array} \\ \text { IV } & 500 \mathrm{ml} \text { of } 0.9 \% \text { saline }\end{array}$

$\mathrm{CFU}=$ Colony-forming units.

capillary refill time, skin elasticity, tension and sensitivity of the abdominal wall, intestinal sounds and other observations, if necessary.

Data were analyzed using a randomized design, and Tukey test was used to compare data obtained from the two groups at each observation time and results were considered to be significant at the $\mathrm{P}<0.05$ level.

\section{RESULTS}

Physical examination of the animals before inoculation did not show any abnormality in any parameter recorded. Rectal temperature was significantly increased from 6 to 8 HAI when compared to the control group (table 2). Significant tachycardia was detected in groups I, II and III at times between 8 and 120 HAI (table 3 ). Only the horses of group III showed an increased in respiratory rate at $10 \mathrm{HAI}$ (table 4). All the inoculated animals showed other clinical signs which are listed in tables 5,6 and 7. It is important to emphasize that the increase in sensitivity and tension of the abdominal wall were more intense in group I when compared to the other groups. Abdominal pain and diarrhea were more intense in the group III. The animals of control group (group IV) did not shown any clinical signs.

\section{DISCUSSION}

Sensitivity and tension of the abdominal wall, diarrhea, an increase in intestinal sounds followed by a decrease and hyperthermia were the clinical signs more frequently observed in horses inoculated with $\boldsymbol{E}$. coli, B. fragilis or with a combination of $\boldsymbol{E}$. coli and $\boldsymbol{B}$. fragilis. These signs were similar to those occurring in natural peritonitis in horses (COFFMAN \& TRISCHLER, 1972; DYSON, 1983; CLABOUGH \& DUSKETT, 1992; 
Table 2 - F values, coefficient of variation $(\mathrm{CV} \%)$ and means for the four groups of horses studied -Rectal temperature $\left({ }^{\circ} \mathrm{C}\right)$.

\begin{tabular}{|c|c|c|c|c|c|c|c|c|c|c|c|c|c|c|c|}
\hline & \multicolumn{15}{|c|}{ Hours after inoculation } \\
\hline & 0 & 2 & 4 & 6 & 8 & 10 & 12 & 24 & 36 & 48 & 60 & 72 & 120 & 168 & 216 \\
\hline $\mathrm{F}$ for groups & $4.32^{\mathrm{NS}}$ & $1.19^{\mathrm{NS}}$ & $2.09^{\mathrm{NS}}$ & $7.25^{* *}$ & $3.95^{*}$ & $2.84^{\mathrm{NS}}$ & $2.26^{\mathrm{NS}}$ & $1.12^{\mathrm{NS}}$ & $1.89^{\mathrm{NS}}$ & $3.64^{*}$ & $2.22^{\mathrm{NS}}$ & $2.75^{\mathrm{NS}}$ & $2.23^{\mathrm{NS}}$ & $1.09^{\mathrm{NS}}$ & $2.67^{\mathrm{NS}}$ \\
\hline $\mathrm{CV}(\%)$ & 1.10 & 1.38 & 1.75 & 1.19 & 1.51 & 1.53 & 1.58 & 2.09 & 1.93 & 1.48 & 1.63 & 1.80 & 1.49 & 1.09 & 1.55 \\
\hline Mean GI & $37.95^{\mathrm{A}}$ & $38.32^{\mathrm{A}}$ & $39.10^{\mathrm{A}}$ & $39.00^{\mathrm{A}}$ & $39.05^{\mathrm{A}}$ & $39.10^{\mathrm{A}}$ & $39.05^{\mathrm{A}}$ & $37.80^{\mathrm{A}}$ & $38.97^{\mathrm{A}}$ & $38.40^{\mathrm{A}}$ & $38.70^{\mathrm{A}}$ & $38.27^{\mathrm{A}}$ & $38.12^{\mathrm{A}}$ & $37.97^{\mathrm{A}}$ & $37.87^{\mathrm{A}}$ \\
\hline Mean GII & $37.10^{\mathrm{A}}$ & $37.95^{\mathrm{A}}$ & $38.65^{\mathrm{A}}$ & $39.25^{\mathrm{A}}$ & $39.12^{\mathrm{A}}$ & $39.17^{\mathrm{A}}$ & $39.27^{\mathrm{A}}$ & $37.72^{\mathrm{A}}$ & $38.05^{\mathrm{A}}$ & $37.15^{\mathrm{B}}$ & $37.87^{\mathrm{A}}$ & $37.52^{\mathrm{A}}$ & $37.35^{\mathrm{A}}$ & $37.52^{\mathrm{A}}$ & $37.15^{\mathrm{A}}$ \\
\hline Mean GIII & $37.62^{\mathrm{A}}$ & $38.20^{\mathrm{A}}$ & $38.32^{\mathrm{A}}$ & $38.97^{\mathrm{A}}$ & $39.10^{\mathrm{A}}$ & $39.02^{\mathrm{A}}$ & $39.05^{\mathrm{A}}$ & $37.97^{\mathrm{A}}$ & $38.92^{\mathrm{A}}$ & $38.10^{\mathrm{AB}}$ & $38.90^{\mathrm{A}}$ & $38.73^{\mathrm{A}}$ & $38.23^{\mathrm{A}}$ & $37.43^{\mathrm{A}}$ & $38.20^{\mathrm{A}}$ \\
\hline Mean GIV & $37.30^{\mathrm{A}}$ & $37.67^{\mathrm{A}}$ & $37.95^{\mathrm{A}}$ & $37.85^{\mathrm{B}}$ & $37.95^{\mathrm{B}}$ & $38.10^{\mathrm{A}}$ & $38.22^{\mathrm{A}}$ & $37.10^{\mathrm{A}}$ & $38.22^{\mathrm{A}}$ & $37.52^{\mathrm{AB}}$ & $38.30^{\mathrm{A}}$ & $37.42^{\mathrm{A}}$ & $37.17^{\mathrm{A}}$ & $37.15^{\mathrm{A}}$ & $36.97^{\mathrm{A}}$ \\
\hline
\end{tabular}

NS -Non significant

* - $\mathrm{P}<0.05$ compared between groups at the same time.

$* *$ - $\mathrm{P}<0.01$ compared between groups at the same time.

Table 3 - F values, coefficient of variation (CV\%) and means for the four groups of horses studied - Heart rate (bpm).

\begin{tabular}{|c|c|c|c|c|c|c|c|c|c|c|c|c|c|c|c|}
\hline & \multicolumn{15}{|c|}{ Hours after inoculations } \\
\hline & 0 & 2 & 4 & 6 & 8 & 10 & 12 & 24 & 36 & 48 & 60 & 72 & 120 & 168 & 216 \\
\hline $\mathrm{F}$ for groups & $0.85^{\mathrm{ns}}$ & $2.36^{\mathrm{ns}}$ & $2.28^{\mathrm{ns}}$ & $2.88^{\mathrm{ns}}$ & $8.16^{* *}$ & $6.85^{* *}$ & $3.45^{\mathrm{ns}}$ & $6.54^{* *}$ & $4.69^{*}$ & $8.64^{* *}$ & $5.69^{*}$ & $7.72^{* *}$ & $11.31^{* *}$ & $3.20^{\mathrm{ns}}$ & $2.54^{\mathrm{ns}}$ \\
\hline $\mathrm{CV}(\%)$ & 12.06 & 25.35 & 25.92 & 21.34 & 20.23 & 25.26 & 21.57 & 22.17 & 24.47 & 17.60 & 21.40 & 13.73 & 12.45 & 16.23 & 18.36 \\
\hline Mean GI & $42.00^{\mathrm{A}}$ & $61.00^{\mathrm{A}}$ & $66.00^{\mathrm{A}}$ & $61.00^{\mathrm{A}}$ & $66.00^{\mathrm{AB}}$ & $64.00^{\mathrm{AB}}$ & $67.00^{\mathrm{A}}$ & $53.00^{\mathrm{AB}}$ & $58.00^{\mathrm{AB}}$ & $50.00^{\mathrm{AB}}$ & $46.00^{\mathrm{AB}}$ & ${ }^{3} 47.00^{\mathrm{AC}}$ & $48.00^{\mathrm{A}}$ & $46.00^{\mathrm{A}}$ & $45.00^{\mathrm{A}}$ \\
\hline Mean GII & $38.00^{\mathrm{A}}$ & $63.00^{\mathrm{A}}$ & $69.00^{\mathrm{A}}$ & $53.00^{\mathrm{A}}$ & $52.00^{\mathrm{B}}$ & $49.00^{\mathrm{B}}$ & $54.00^{\mathrm{A}}$ & $37.00^{\mathrm{B}}$ & $38.00^{\mathrm{B}}$ & $40.00^{\mathrm{B}}$ & $41.00^{\mathrm{B}}$ & $38.00^{\mathrm{BC}}$ & $36.00^{\mathrm{B}}$ & $40.00^{\mathrm{A}}$ & $42.00^{\mathrm{A}}$ \\
\hline Mean GIII & $43.00^{\mathrm{A}}$ & $72.00^{\mathrm{A}}$ & $64.00^{\mathrm{A}}$ & $69.00^{\mathrm{A}}$ & $81.00^{\mathrm{A}}$ & $85.00^{\mathrm{A}}$ & $64.50^{\mathrm{A}}$ & $65.00^{\mathrm{A}}$ & $66.00^{\mathrm{A}}$ & $63.50^{\mathrm{A}}$ & $65.00^{\mathrm{A}}$ & $57.33^{\mathrm{A}}$ & $54.67^{\mathrm{A}}$ & $53.33^{\mathrm{A}}$ & $54.67^{\mathrm{A}}$ \\
\hline Mean GIV & $41.00^{\mathrm{A}}$ & $44.00^{\mathrm{A}}$ & $43.00^{\mathrm{A}}$ & $45.00^{\mathrm{A}}$ & $41.00^{\mathrm{B}}$ & $40.00^{\mathrm{B}}$ & $42.00^{\mathrm{A}}$ & $37.00^{\mathrm{B}}$ & $41.00^{\mathrm{AB}}$ & $36.00^{\mathrm{B}}$ & $38.00^{\mathrm{B}}$ & $38.00^{\mathrm{BC}}$ & $35.00^{\mathrm{B}}$ & $38.00^{\mathrm{A}}$ & $38.00^{\mathrm{A}}$ \\
\hline
\end{tabular}

NS-Non significant

* $-\mathrm{P}<0.05$ compared between groups at the same time

** $-\mathrm{P}<0.01$ compared between groups at the same time

Table 4 - F values, coefficient of variation (CV\%) and means for the four groups of horses studied -Respiratory rate (mpm).

\begin{tabular}{|c|c|c|c|c|c|c|c|c|c|c|c|c|c|c|c|}
\hline & \multicolumn{15}{|c|}{ Hours after inoculations } \\
\hline & 0 & 2 & 4 & 6 & 8 & 10 & 12 & 24 & 36 & 48 & 60 & 72 & 120 & 168 & 216 \\
\hline $\mathrm{F}$ for groups & $0.39^{\mathrm{NS}}$ & $1.56^{\mathrm{NS}}$ & $2.86^{\mathrm{NS}}$ & $0.23^{\mathrm{NS}}$ & $2.55^{\mathrm{NS}}$ & $4.06^{*}$ & $2.37^{\mathrm{NS}}$ & $0.16^{\mathrm{NS}}$ & $1.06^{\mathrm{NS}}$ & $1.96^{\mathrm{NS}}$ & $3.06^{\mathrm{NS}}$ & $2.84^{\mathrm{NS}}$ & $2.58^{\mathrm{NS}}$ & $1.65^{\mathrm{NS}}$ & $0.11^{\mathrm{NS}}$ \\
\hline $\mathrm{CV}(\%)$ & 45.81 & 42.72 & 36.00 & 48.73 & 35.36 & 30.34 & 36.58 & 30.50 & 50.83 & 39.44 & 33.84 & 42.54 & 18.78 & 31.73 & 36.47 \\
\hline Mean GI & $19.00^{\mathrm{A}}$ & $31.00^{\mathrm{A}}$ & $38.00^{\mathrm{A}}$ & $28.00^{\mathrm{A}}$ & $31.00^{\mathrm{A}}$ & $23.00^{\mathrm{AB}}$ & $19.00^{\mathrm{A}}$ & $17.00^{\mathrm{A}}$ & $30.00^{\mathrm{A}}$ & $25.00^{\mathrm{A}}$ & $24.00^{\mathrm{A}}$ & $15.00^{\mathrm{A}}$ & $16.00^{\mathrm{A}}$ & $14.00^{\mathrm{A}}$ & $18.00^{\mathrm{A}}$ \\
\hline Mean GII & $17.00^{\mathrm{A}}$ & $50.00^{\mathrm{A}}$ & $46.00^{\mathrm{A}}$ & $34.00^{\mathrm{A}}$ & $39.00^{\mathrm{A}}$ & $28.00^{\mathrm{AB}}$ & $21.00^{\mathrm{A}}$ & $17.00^{\mathrm{A}}$ & $17.00^{\mathrm{A}}$ & $13.00^{\mathrm{A}}$ & $16.00^{\mathrm{A}}$ & $14.00^{\mathrm{A}}$ & $13.00^{\mathrm{A}}$ & $17.00^{\mathrm{A}}$ & $16.00^{\mathrm{A}}$ \\
\hline Mean GIII & $15.00^{\mathrm{A}}$ & $41.00^{\mathrm{A}}$ & $28.00^{\mathrm{A}}$ & $26.00^{\mathrm{A}}$ & $28.00^{\mathrm{A}}$ & $37.00^{\mathrm{A}}$ & $33.00^{\mathrm{A}}$ & $17.00^{\mathrm{A}}$ & $31.00^{\mathrm{A}}$ & $22.00^{\mathrm{A}}$ & $32.50^{\mathrm{A}}$ & $30.67^{\mathrm{A}}$ & $18.67^{\mathrm{A}}$ & $13.33^{\mathrm{A}}$ & $16.00^{\mathrm{A}}$ \\
\hline Mean GIV & $21.00^{\mathrm{A}}$ & $28.00^{\mathrm{A}}$ & $23.00^{\mathrm{A}}$ & $30.00^{\mathrm{A}}$ & $19.00^{\mathrm{A}}$ & $18.00^{\mathrm{B}}$ & $20.00^{\mathrm{A}}$ & $15.00^{\mathrm{A}}$ & $33.00^{\mathrm{A}}$ & $17.00^{\mathrm{A}}$ & $21.00^{\mathrm{A}}$ & $21.00^{\mathrm{A}}$ & $18.00^{\mathrm{A}}$ & $16.00^{\mathrm{A}}$ & $16.00^{\mathrm{A}}$ \\
\hline
\end{tabular}

NS -Non significant

* $-\mathrm{P}<0.05$ compared between groups at the same time

$* *$ - $\mathrm{P}<0.01$ compared between groups at the same time

Ciência Rural, v. 29, n. 3, 1999. 
Table 5 - Clinical signs observed in group I*.

\begin{tabular}{|c|c|c|}
\hline Horses & Clinical Signs & Hours after inoculations \\
\hline \multirow{5}{*}{1} & Sensitivity of abdominal wall & $4,6,8,10,12,24,36$ and 48 \\
\hline & Tension of abdominal wall & $4,6,8,10,12,24,36$ and 48 \\
\hline & Increased intestinal sounds & 2,48 and 60 \\
\hline & Decreased intestinal sounds & $4,6,8,10,12$ and 24 \\
\hline & Diarrhea & 2 \\
\hline \multirow{5}{*}{2} & Sensitivity of abdominal wall & $2,4,6,8,10$ and 12 \\
\hline & Tension of abdominal wall & $2,4,6,8,10$ and 12 \\
\hline & Increased intestinal sounds & 2 \\
\hline & Decreased intestinal sounds & $4,6,8,10$ and 12 \\
\hline & Diarrhea & 2 \\
\hline \multirow{5}{*}{3} & Sensitivity of abdominal wall & $2,4,6,8,10,12$ and 24 \\
\hline & Tension of abdominal wall & $2,4,6,8,10,12$ and 24 \\
\hline & Decreased intestinal sounds & $2,4,6,8,10$ and 12 \\
\hline & Diarrhea & 2 \\
\hline & Recumbence & 2 \\
\hline \multirow{5}{*}{4} & Sensitivity of abdominal wall & $2,4,6,8,10$ and 12 \\
\hline & Tension of abdominal wall & $4,6,8,10$ and 12 \\
\hline & Increased intestinal sounds & 2 \\
\hline & Decreased intestinal sounds & $\begin{array}{l}4,6,8,10,12,24,48,60 \text { and } \\
72\end{array}$ \\
\hline & Diarrhea & 2 and 36 \\
\hline
\end{tabular}

* Horses inoculated intraperitoneally with $100 \times 10^{7} \mathrm{CFU}$ of $\boldsymbol{E}$. coli

Table 6 - Clinical signs observed in group II*.

\begin{tabular}{cll}
\hline \multirow{2}{*}{ Horses } & \multicolumn{1}{c}{ Clinical Signs } & Hours after inoculations \\
& & \\
& & \\
& & \\
& Increased intestinal sounds & 24 \\
& Decreased intestinal sounds & $6,8,10$ and 12 \\
& Diarrhea & 2 and 4 \\
& Recumbence & 4 \\
& Turning the head toward the flank & 10 \\
& Restlessness & 10 \\
& & \\
& Sensitivity of abdominal wall & 24 \\
6 & Tension of abdominal wall & $4,6,8$ and 10 \\
& Decreased intestinal sounds & $2,4,6,8$ and 10 \\
& Diarrhea & 2 \\
& Sensitivity of abdominal wall & 24 \\
7 & Tension of abdominal wall & $2,4,6,8,10,12$ and 24 \\
& Diarrhea & 2 \\
& Decreased intestinal sounds & $2,4,6,8,10$ and 12 \\
& Tension of abdominal wall & 2,4 and 6 \\
& Diarrhea & 2 \\
& Restlessness & 2 \\
& &
\end{tabular}

*Horses inoculated intraperitoneally with $100 \times 10^{7}$ CFU of $\boldsymbol{B}$. Fragilis.
MAIR et al., 1990; MOLL \& SCHUMACHER, 1992), and when present they are indicative of clinical peritonitis occurrence.

Clinical signs were more intense and more prolonged in animals inoculated with the combination of bacteria when compared with single inoculation of $\boldsymbol{E}$. coli or $\boldsymbol{B}$. fragilis. These findings suggest that synergism occurred in horses experimentally inoculated with $\boldsymbol{E}$. coli and B. fragilis, and mortality was only observed in one animal of this group (III).

Statistically significant hyperthermia was detected in all inoculated groups only at times 6 and $8 \mathrm{HAI}$, although isolated peaks occurred in all inoculated animals until 60 HAI. Previous studies of peritonitis in equine reported normothermia (COFFMAN \& TRISCHLER, 1972; MOLL \& SCHUMACHER, 1992) and hyperthermia intermittent (DYSON, 1972; MAIR et al., 1990). Release of exogenous pyrogens occurs in infectious or inflammatory processes stimulating neutrophils and eosinophils to produce interleukin 1 (IL-1) (WHITE II, 1990). Hyperthermia is a central response for IL-1 release. In addition, release of prostaglandin $E_{2}$ occurs in inflammation and endotoxemia and is responsible for increases in rectal temperature (WHITE II, 1990). Therefore the increases in rectal temperature observed in the horses with experimental peritonitis were important only until 6 HAI.

Statistically significant tachycardia occurred in all inoculated groups between 8 and $120 \mathrm{HAI}$. Several investigators have suggested that alterations occur in response to fluid loss, toxin absorption and release of inflammatory mediators (KUNESH, 1984; HOSGOOD \& SALISBURY, 1989; MAIR et al., 1990; BONOUS, 1993; HAWKINS et al., 1993).

Only animals in group III, inoculated with $\boldsymbol{E}$. coli and $\boldsymbol{B}$. fragilis presented a significant increase of respiratory rate. Tachypnea occurs as a consequence of toxin absorption by peritoneum (BONOUS, 1993). This finding reinforces the hypothesis that the combination of these bacteria produces a greater pathogenicity than when each is injected alone. B. fragilis in pure culture, when injected intraperitoneally into rats, presents low pathogenicity (WHITE, 1990). Likewise, E. coli is also more pathogenic for rats when combined with adjuvant factors that favour bacterial growth, such as hemoglobin (HAU et al., 1978).

We conclude that the prompt clinical examination is important for the evaluation and prognosis of peritonitis, since some clinical signs will only be observed in the early phase of this 
Table 7 - Clinical signs observed in group III*.

\begin{tabular}{|c|c|c|}
\hline Horses & Clinical Signs & Hours after inoculations \\
\hline \multirow{7}{*}{9} & Depression & 2 \\
\hline & Tension of abdominal wall & $\begin{array}{l}2,4,6,8,10,12,24,36 \\
\text { and } 48\end{array}$ \\
\hline & Recumbence & 2 e 4 \\
\hline & Decreased intestinal sounds & $4,6,8,10,12$ and 24 \\
\hline & Diarrhea & 2 \\
\hline & Cyanotic mucous membranes & 8,10 and 12 \\
\hline & Death & 60 \\
\hline \multirow{6}{*}{10} & Sensitivity of abdominal wall & $60,72,96$ and 168 \\
\hline & Tension of abdominal wall & $\begin{array}{l}2,4,6,8,10,12,24,36 \\
48,60,72,96,120 \text { and } \\
168\end{array}$ \\
\hline & Depression & 2 and 60 \\
\hline & Decreased intestinal sounds & $\begin{array}{l}2,4,6,8,10,12,60,72 \\
\text { and } 168\end{array}$ \\
\hline & Diarrhea & 72 \\
\hline & Inappetence & 72 \\
\hline \multirow{6}{*}{11} & Sensitivity of abdominal wall & $\begin{array}{l}2,4,8,10,12,24,48 \\
\text { and } 72\end{array}$ \\
\hline & Tension of abdominal wall & $\begin{array}{l}2,4,6,8,10,12,24,36 \\
48,60,72,96 \text { and } 120\end{array}$ \\
\hline & Recumbence & 2 \\
\hline & Decreased intestinal sounds & $\begin{array}{l}2,4,6,8,10,12,24,36 \\
48 \text { and } 60\end{array}$ \\
\hline & Diarrhea & 2 and 4 \\
\hline & Cyanotic mucous membranes & 6 \\
\hline \multirow{5}{*}{12} & $\begin{array}{l}\text { Sensitivity of abdominal } \\
\text { wall }\end{array}$ & $\begin{array}{l}8,10,12,24,36,48,60, \\
72,96 \text { and } 120\end{array}$ \\
\hline & Tension of abdominal wall & $\begin{array}{l}2,4,6,8,10,12,24,36, \\
48,60,72,96,120 \text { and } \\
168\end{array}$ \\
\hline & Pale mucous membranes & 2 \\
\hline & Decreased intestinal sounds & $\begin{array}{l}2,4,6,8,10,12,24,36 \\
48 \text { and } 60\end{array}$ \\
\hline & Diarrhea & 2 \\
\hline
\end{tabular}

*Horses inoculated intraperitoneally with $100 \times 10^{7} \mathrm{CFU}$ of $\boldsymbol{E}$. coli $+100 \times 10^{7} \mathrm{CFU}$ of $\boldsymbol{B}$. fragilis.

condition. Horses inoculated with pure cultures of either $\boldsymbol{E}$. coli or $\boldsymbol{B}$. fragilis demonstrated mild and self-limiting peritonitis, while those inoculated with the combination of both bacteria demonstrated clinical signs of higher intensity and duration.

\section{REFERENCES}

BONOUS, D.I. Test your diagnostic skill. Comp Cont Edu Pract Vet, v. 15, p. 611-613, 1993.

ClABOUGH, D.L., DUCKETT, W. Septic cholangitis and peritonitis in a gelding. J Am Vet Med Assoc, v. 200, p. 1521-1524, 1992.
COFFMAN, J.R., TRISCHLER, L.G. Exudative peritonitis in two horses. J Am Vet Med Assoc, v. 160, p. 871-872, 1972.

DYSON, S. Review of 30 cases of peritonitis in the horse. Eq Vet J, v. 15 , p. $25-30,1983$.

EDWARDS, P.R., EWING, W.H. Identification of Enterobacteriaceae. Minneapolis:Burges Publishing, 1972. p. 82-105.

HAU, T., HOFFMAN, R., SIMMONS, R.L. Mechanisms of the adjuvant effect of hemoglobin in experimental peritonitis I. In vivo inhibition of peritoneal leukocytosis. Surgery, v. 83, p. 223-229, 1978.

HAWKINS, J.P., BOWMAN, K.F., ROBERTS, M.C., $\boldsymbol{e}$ t al. Peritonitis in horses: 67 cases (1985-1990). J Am Vet Med Assoc, v. 203, p. 284-288, 1993.

HOSGOOD, G.L., SALISBURY, S.K. Pathophysiology and pathogenesis of generalized peritonitis. Problems in Vet Med, v. 1, p. 159-167, 1989.

JANG, S.S., HIRSH, D.C. Identity of Bacteroides isolates and previously named Bacteroides spp in clinical specimens of animal origin. Am J Vet Res, v. 52, p. 738-741, 1991.

KUNESH, J.P. Therapeutic strategies involving antimicrobial treatment of large animal peritonitis. J Am Vet Med Assoc, v. 185, p. 1222-1225, 1984.

MAIR, T.S., HILLYER, M.H., TAYLOR, F.G.R. Peritonitis in adult horses: A review of 21 cases. Vet Rec, v. 126, p. 567$570,1990$.

MOLL, D.H., SCHUMACHER, J. Septic peritonitis associated with caudal myotomy in a tennessee walking horse. J Am Vet Med Assoc, v. 201, p. 458-459, 1992.

MOORE, R.M. Pathogenesis of obligate anaerobic bacterial infections in horses. Comp Cont Edu Pract Vet, v.15, p. 278$287,1993$.

RICKETTS, S.N. Peritonitis. In: ROBINSON, N.E. Current therapy in equine medicine. 2. ed. Philadelphia: Saunders, 1987. p. 79-81.

SCHNEIDER, R.K. Peritonitis. In: MANSMAN, R.A., MCALLISTER, E. S. Equine Medicine and Surgery. 3. ed. Santa Barbara: Am. Vet., 1982. p. 620-632.

SEMRAD, S.D. Peritonitis In: SMITH, B.P. Large animal internal medicine. Saint Louis: Mosby, 1990. p. 674-679.

TRENT, A.M. The peritoneum and peritoneal cavity. In: KOBLUK. (ed) The Horse diseases \& clinical management. Philadelphia: Sauders, 1995. p. 373-401.

WHITE II, N.A. The equine acute abdomen. Philadelphia: Lea \& Febiger, 1990. 443 p.

WHITE, S.L. Alterations in body temperature. In: SMITH, B. P. Large animal internal medicine. Saint Louis: Mosby, 1990. p. $35-46$.

Ciência Rural, v. 29, n. 3, 1999. 